\title{
Review Paper: Endocrine-Disrupting Chemicals Role in Drug Abuser: A Review Study
}

\author{
Idha Arfianti Wiraagni',2 (D, Mustafa Ali Mohd³, Rusdi Abdul Rashid* (D, Didi Erwandi Bin Mohamad Haron ${ }^{3}$
}

1. Department of Pathology, Faculty of Medicine, University of Malaya, Kuala Lumpur, Malaysia.

2. Department of Forensic Medicine and Medicolegal, Faculty of Medicine, Universitas Gadjah Mada, Yogyakarta, Indonesia.

3. Shimadzu-UM Center for Xenobiotics Studies (SUCXeS), Faculty of Medicine, University of Malaya, Kuala Lumpur, Malaysia.

4. Department of Psychological Medicine, Faculty of Medicine, University of Malaya, Kuala Lumpur, Malaysia.

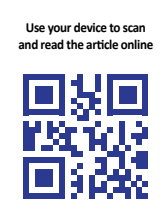

Citation: Arfianti Wiraagni I, Ali Mohd M, Abdul Rashid R, Erwandi Bin Mohamad Haron D. Endocrine-Disrupting Chemicals Role in Drug Abuser: A Review Study. International Journal of Medical Toxicology and Forensic Medicine. 2020; 10(4):26324. https://doi.org/10.32598/ijmtfm.v10i4.26324

doi https://doi.org/10.32598/ijmtfm.v10i4.26324

\section{(1) (8)}

Article info:

Received: 10 Jul 2019

First Revision: 11 Jul 2019

Accepted: 01 Jul 2020

Published: 06 Dec 2020

Keywords:

EDCs, Bisphenol, Paraben

\section{A B S T RACT}

Endocrine-disrupting Chemicals (EDCs) are exogenous chemicals that influence many aspects of natural hormone actions. Bisphenol is used in the industry, for increasing the thickness and durability of materials in certain plastics and resins. Paraben is used as preservatives in many pharmaceuticals, cosmetics, and some food products. EDCs can increase estrogen levels inside the body, and estrogen itself can increase the monoamine effect (dopamine, serotonin), neuronal excitability, neuropeptide transmitter mechanism, and drug metabolism. In drug abusers, this effect can develop greater craving behavior, addiction, and relapse.

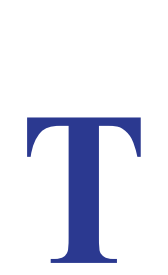

\section{Introduction}

he modern-day environment is filled with thousands of synthetic chemicals and compounds used in everyday life. These chemicals are found in the environment and most of them are used by humans. Some of these chemicals are useful and beneficial to the human body while numerous other chemicals were toxic and can cause undesirable effects. Exposure to these chemicals can be through various ways and the effects can range from minor or trace to carcinogenic. Developing countries like Malaysia are among the highest users of vari- ous types of man-made chemicals in a large number of consumer products, such as cosmetics, soaps, shampoos, electronic gadgets, textile, perfumes, paints, fertilizers, and pesticides. The development in the industry has caused a negative impact on the environment. Each year numerous new compounds with unknown effects on human health are being created and eventually found their way into the environment. These contaminations have caused public concerns that man-made chemicals might give negative health effects on the population. Many of these synthetic chemicals possess estrogenic activity and have been classified as endocrine-disrupting chemicals (EDCs) [1].

* Corresponding Author:

Rusdi Abdul Rashid, PhD.

Address: Department of Psychological Medicine, Faculty of Medicine, University of Malaya, Kuala Lumpur, Malaysia.

Tel: +60 (13) 3556891

E-mail: rusdi@um.edu.my 
Multiple research studies have connected EDCs to cancer, diabetes, obesity, and infertility in humans [1-3]. EDCs can block, mimic, or modulate the synthesis, release, transport, metabolism, and binding or elimination of natural hormones. Therefore, any disruption in this system will cause an abnormal function or development in the reproductive, nervous, and immune systems. EDCs may generate a harmful effect even if they are present in the environment at very low or trace levels [4]. Exposures to known EDCs are relatively high in contaminated environments. Industrial chemicals can leak into soil and water. Then, they are consumed by microorganisms, algae, and plants.

Animals eat plants, and bigger animals eat smaller ones. Accordingly, animals at the top of the food chain, including humans, have the highest concentrations of such environmental chemicals in their tissues. EDCs include polycarbonate by-products, surfactants such as octylphenol, insecticides such as dichlorodiphenyltrichloroethane (DDT) and its metabolites, endosulfan, phthalate, polychlorinated biphenyls (PCBs), dioxins, alkylphenols (APs), bisphenol, parabens, pesticides, and polycyclic aromatic hydrocarbons (PAHs) $[1,2,5,6]$.

\section{Review of EDCs}

\subsection{Bisphenol}

\subsubsection{Properties}

Bisphenol (Figure 1) is an industrial chemical that has been used to make certain plastics and resins since the 1960s. It is used in the industry for increasing the thickness and durability of materials. Bisphenol is frequently used in polycarbonate plastic, food storage containers, reusable drink containers, children's toys, and canned foods. It is released from consumer goods, leading to its detection in wastewater, drinking water, soil, dust, food, and air. Bisphenol A (BPA's) global annual output is approximately 6.8 million tonnes [7-10].

Polycarbonate plastic is used to make sports equipment, CDs, DVDs, baby and water bottles, foundry castings, medical, and dental devices, household electronics, eyeglass lenses, and water pipes lining [2, 11, 12]. Bisphenol A (BPA,), Bisphenol B (BPB,), Bisphenol S (BPS,), Bisphenol F (BPF,), and Bisphenol AF (BPAF) were studied in this research (Table 1). Bisphenols are mostly soluble in ethanol, acetone, methanol, benzene, chloroform, and ether [12-14].

\subsubsection{Pharmacology}

In the workplace, in which bisphenol products are produced, inhalation and dermal exposures are the most probable routes of toxicity. While in the general population, major exposure to bisphenol is via the oral route (ingestion of contaminated food and water) [15-19]. Some foods and water are stored in food cans, which are lined with BPA epoxy resin films. In the pediatric population (infants and children), milk and beverage bottles provide daily exposure to BPA [7, 20]. Bisphenol $\mathrm{A}$ in human volunteers is absorbed rapidly via the gastrointestinal tract. Metabolism is performed in the liver with a rapid conjugation process with UDP-glucuronic acid, forming BPAG (BPA glucuronide). BPA glucuronide is rapidly formed and excreted via urine, feces, or bile, with a halflife of about 5.3 hours. All of these processes are complete within 24 hours [21]. The fetus and newborn can receive BPA from the mother via placental transfer and milk. One study showed that BPA could be detected in sweat and induced sweating is a clinically useful method to eliminate BPA from the body [22].

\subsubsection{Toxicity}

BPA similar to endogenous estrogen which can bind with estrogen receptors, stimulate estrogen production, and also alter gonadotropin hormone secretion [23, 24]. These mechanisms can stimulate endometriosis formation. Some studies found the association of urinary BPA concentrations with semen quality. In male Chinese workers, who were highly exposed to BPA (median urinary $\mathrm{BPA}$ concentration $=38.7 \mathrm{ug} / \mathrm{L}$ ), sperm concentration, total count, and activity had reduced [7, 16, 17]. Research in men partners of the infertile couple showed a positive correlation between BPA level in urine and abnormal sperm morphology [25].

In 84 women undergoing treatment with InVitro Fertilization (IVF), a reported correlation is seen between BPA level in urine $($ median $=2.6 \mathrm{ug} / \mathrm{L})$ with reduced oocyte yield and peak serum estradiol [26-28]. One cross-sectional study on 192 female teenagers showed a possible association between later onset of breast development and higher urinary BPA level [29, 30]. Another research was held in the third trimester of 367 pregnant women that had $1.3 \mu \mathrm{g} / \mathrm{L}$ urinary BPA concentration. There was a modest elevation in neonatal birth weight [30]. While cohort study in 249 pregnant women (with $2.0 \mu \mathrm{g} / \mathrm{L}$ urinary BPA concentration) had a positive association with children externalizing behaviors (such as aggression and hyperactivity) using the behavioral assessment system for children-2 (BASC-2) [31-33]. 


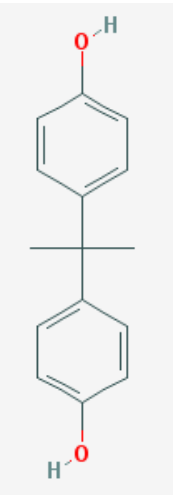

BPA

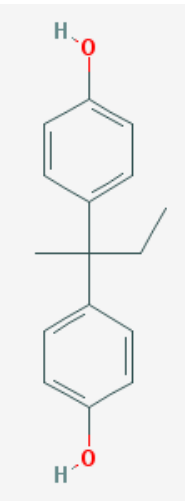

BPB

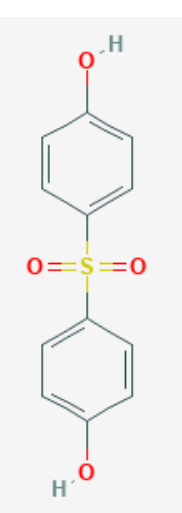

BPS

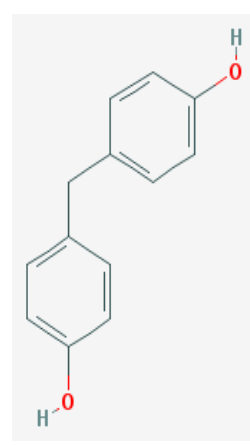

BPF

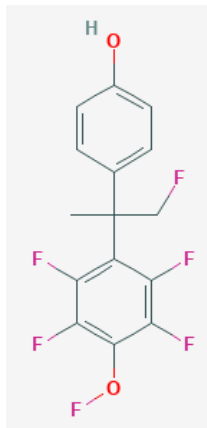

BPAF

Figure 1. Structure of bisphenols

\subsubsection{Biologic monitoring}

For bisphenol human biologic monitoring, some studies used various matrices such as placental tissue, urine, serum, semen, blood, amniotic fluid, breast milk, follicular fluid, and umbilical cord blood (Table 2). Bisphenol A can pass the maternal-fetal placental barrier, so mother and baby serum, amniotic fluid, cord blood, and placental detection suggest the risk of fetal exposure to Bisphenol A [34, 35]. Analytical techniques applied for measuring bisphenol in the human matrix are GC-MS, LC-MS, LC-MS/MS, and enzyme-linked immunosorbent assay. Glucuronidase treatment for urine is important to do for releasing glucuronic acid conjugation, then extracted by SPE, LLE, stir bar sorptive extraction, and SPME $[6,36]$.

\subsection{Paraben}

\subsubsection{Properties}

One of the groups of alkyl esters of the p-hydroxybenzoic acid, broadly used as preservatives in pharmaceutical, food, and personal care products are called parabens. This group includes methylparaben, ethylparaben, propylparaben, isopropylparaben, butylparaben, isobutylparaben, and benzylparaben. Methylparaben, ethylparaben, propylparaben, and butylparaben were studied in this research (Figure 2). These chemicals have simple esters with effective antimicrobial and antifungal properties. Although they have low toxicity, parabens belong to EDCs [39]. Products found to contain parabens include hand soap, body lotion, shampoo, conditioner, cosmetics, hair spray, toothpaste, jams, jellies, fillings, and toppings [40]. In the environment, parabens are detected in urban streams, rivers, and drinking water sources [41].

Table 1. Properties of bisphenols

\begin{tabular}{|c|c|c|c|c|c|c|}
\hline No. & Compound & Physical Description & Color & Odor & Boiling Point & Melting Point \\
\hline 1 & $\begin{array}{c}\text { BPA } \\
\text { 2,2-Bis (4-hydroxyphenyl) } \\
\text { Propane }\end{array}$ & $\begin{array}{l}\text { Dry powder, liquid, } \\
\text { other solid, pellets } \\
\text { large crystal. }\end{array}$ & $\begin{array}{c}\text { White flakes to } \\
\text { cream }\end{array}$ & $\begin{array}{l}\text { Mild phenolic } \\
\text { odor }\end{array}$ & $360.5^{\circ} \mathrm{C}$ & $153^{\circ} \mathrm{C}$ \\
\hline 2 & $\begin{array}{c}\text { BPB } \\
\text { 2,2-Bis (4-hydroxyphenyl) } \\
\text { butane }\end{array}$ & Crystal, dry powder & $\begin{array}{l}\text { Crystal or tan } \\
\text { granule }\end{array}$ & Mild odor & $120.5^{\circ} \mathrm{C}$ & $125^{\circ} \mathrm{C}-127^{\circ} \mathrm{C}$ \\
\hline 3 & $\begin{array}{c}\text { BPS } \\
\text { Bis(4-hydroxyphenyl) } \\
\text { Sulfone }\end{array}$ & Dry powder & $\begin{array}{l}\text { White crystal- } \\
\text { line powder }\end{array}$ & Mild odor & $505^{\circ} \mathrm{C}$ & $240.5^{\circ} \mathrm{C}$ \\
\hline 4 & $\begin{array}{c}\text { BPF } \\
\text { Bis(4-hydroxyphenyl) } \\
\text { methane }\end{array}$ & Dry powder & White & Mild odor & $390^{\circ} \mathrm{C}$ & $162.5^{\circ} \mathrm{C}$ \\
\hline 5 & $\begin{array}{c}\text { BPAF } \\
\text { 2,2-Bis(4-hydroxyphenyl) } \\
\text { hexafluoropropane }\end{array}$ & Tan coarse powder & $\begin{array}{l}\text { White, light } \\
\text { gray }\end{array}$ & Mild odor & $400^{\circ} \mathrm{C}$ & $161^{\circ} \mathrm{C}$ \\
\hline
\end{tabular}


Table 2. Analysis of bisphenol in human biological samples using LC-MS/MS

\begin{tabular}{|c|c|c|c|c|c|}
\hline No. & Analyte & Sensitivity & Sample & Preparation & References \\
\hline 1 & BPA & LOQ: $0.1 \mathrm{ng} / \mathrm{mL}$ & Urine & SPE & [7] \\
\hline 2 & BPA & LOQ: $15 \mu \mathrm{g} / \mathrm{L}$ & $\begin{array}{l}\text { Urine } \\
\text { Plasma }\end{array}$ & Protein precipitation & [21] \\
\hline 3 & BPA & LOQ: 0.05 ng/mL & $\begin{array}{l}\text { Blood } \\
\text { Urine }\end{array}$ & $\begin{array}{l}\text { Protein precipitation } \\
\text { (for blood) } \\
\text { SPE (for urine) }\end{array}$ & [37] \\
\hline 4 & BPS & LOQ: 0.02 ng/mL & Urine & SPE & [38] \\
\hline 5 & BPA and analogs & LOD: $0.04-6.4 \mathrm{ng} / \mathrm{mL}$ & $\begin{array}{l}\text { Urine } \\
\text { Cord blood }\end{array}$ & LLE & [24] \\
\hline
\end{tabular}

Parabens are odorless, tasteless, or numbs the tongue; they are mostly soluble in ethanol, water, methanol, acetone, and ether (Table 3). They are stable under the hydrolysis process during autoclaving and resist saponification. Methylparaben is an antimicrobial, a neuroprotective, and an antifungal agent found naturally in several fruits. Ethylparaben is found in alcoholic beverages, such as white wine, red wine, and sake. Butylparaben and propylparaben are flavoring agents and chemical allergen that promote histamine release. The exposure via food is because of their natural occurrence, their use as a preservative, and leakage from food packaging material $[39,42]$.

\subsubsection{Pharmacology}

The main route of exposure to parabens is via oral and skin penetration. Parabens are rapidly metabolized by the liver (through esterase hydrolysis and glucuronidation by several UGT isoforms), plasma, and in the skin. The hydrolysis in human liver microsomes is conducted more rapidly than in plasma. Then they are converted into p-hydroxybenzoic acid, followed by excretion via urine. They are commonly excreted as glucuronide conjugates, sulfate, and glycine. Paraben glucuronides are more specific compared to 4-hydroxybenzoic acid and have been used as urinary biomarkers of parabens exposure in humans. Personal care products contributes more blood paraben than oral. It is because, in oral exposure, there is fast metabolism conducted by the intestine and liver [42]. Methylparaben and ethylparaben (95\%) are more stable in human plasma compared to propylparaben, butylparaben, and benzylparaben (50\%) after 24 hours. Parabens are substrates of UGT1A8, UGT2B7, UGT1A9, UGT1A1, UGT2B17, and UGT2B15 (UDPglucuronosyltransferase isoforms) [46].

\subsubsection{Toxicity}

Parabens have estrogenic activity because they can bind to estrogen receptors. This mechanism might exert a hormonal impact on the body. They can inhibit an estrogen-inactivating enzyme (17 $\beta$-hydroxysteroid dehydrogenase) [42]. A study showed that high urinary BPA and butylparaben levels are associated with higher sperm DNA damage ( $\mathrm{P}=0.03$ ) [25]. At the cellular level, there are some reports that parabens can disrupt cellular function and cause chromosomal aberration. Parabens belong to lipophilic pollutants that are known to

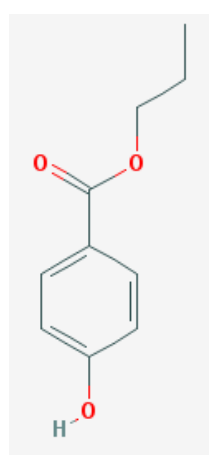

Propylparaben

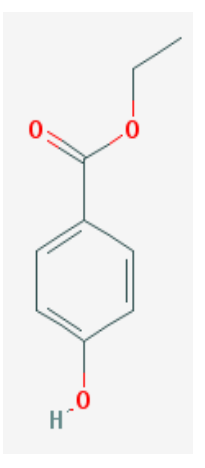

Ethylparaben

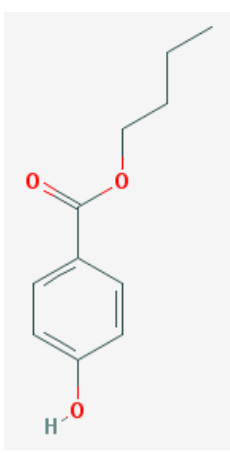

Butylparaben

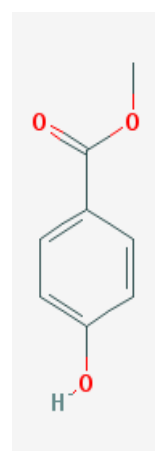

Methylparaben

Figure 2. Structure of parabens 
Table 3. Properties of parabens

\begin{tabular}{|c|c|c|c|c|c|c|}
\hline No. & Compound & Physical Description & Color & Odor & Boiling Point & Melting Point \\
\hline 1 & Propylparaben & Crystals or powder & $\begin{array}{l}\text { Colorless, white powder } \\
\text { or chunky white solid }\end{array}$ & $\begin{array}{l}\text { Odorless or mild } \\
\text { phenolic odor }\end{array}$ & $271^{\circ} \mathrm{F}$ & $95^{\circ} \mathrm{C}-98^{\circ} \mathrm{C}$ \\
\hline 2 & Ethylparaben & Crystals or powder & $\begin{array}{l}\text { Colorless crystals or } \\
\text { white powder }\end{array}$ & Odorless & $297^{\circ} \mathrm{C}-298^{\circ} \mathrm{C}$ & $213^{\circ} \mathrm{C}-217^{\circ} \mathrm{C}$ \\
\hline 3 & Butylparaben & $\begin{array}{c}\text { Small crystals or } \\
\text { powder }\end{array}$ & $\begin{array}{c}\text { Colorless crystals or } \\
\text { powder }\end{array}$ & Odorless & $156^{\circ} \mathrm{C}-157^{\circ} \mathrm{C}$ & $68.5^{\circ} \mathrm{C}$ \\
\hline 4 & Methylparaben & $\begin{array}{c}\text { Small crystals or } \\
\text { powder }\end{array}$ & $\begin{array}{c}\text { Colorless crystals or } \\
\text { powder }\end{array}$ & $\begin{array}{l}\text { Odorless or faint } \\
\text { odor }\end{array}$ & $275^{\circ} \mathrm{C}$ & $131^{\circ} \mathrm{C}$ \\
\hline
\end{tabular}

Table 4. Analysis of paraben in human biological samples using LC-MS/MS

\begin{tabular}{|c|c|c|c|c|c|}
\hline No. & Analyte & Sensitivity & Sample & Preparation & References \\
\hline 1 & $\begin{array}{l}\text { Methylparaben, } \\
\text { ethylparaben, } \\
\text { n-propylparaben, } \mathrm{n} \text {-butylparaben, } \\
\text { isobutylparaben }\end{array}$ & LOQ: 10 ng/g & $\begin{array}{l}\text { Breast tis- } \\
\text { sue }\end{array}$ & LLE & {$[11]$} \\
\hline 2 & $\begin{array}{l}\text { Methylparaben, } \\
\text { ethylparaben, } \\
\text { propylparaben } \\
\text { butylparaben, BPA }\end{array}$ & $\begin{array}{c}\text { LOD MP: } 1.0 \mu \mathrm{g} / \mathrm{L} ; \text { PP and BP: } 0.2 \\
\mu \mathrm{g} / \mathrm{L}\end{array}$ & Urine & SPE & {$[25,47]$} \\
\hline 3 & $\begin{array}{l}\text { Methylparaben, ethylparaben, } \\
\text { n-propylparaben, butylparaben, } \\
\text { benzylparaben }\end{array}$ & $\begin{array}{l}\text { LOD MP: } 0.13 ; \mathrm{ng} / \mathrm{mL} ; \mathrm{PP}: 0.18 \mathrm{ng} / \\
\text { mL, and others: } 0.10 \mathrm{ng} / \mathrm{mL}\end{array}$ & Urine & SPE & {$[43]$} \\
\hline 4 & $\begin{array}{c}\text { Methylparaben, propylparaben, } \\
\text { benzylparaben }\end{array}$ & LOQ: 20 ng/mL & Blood & SPE & [49] \\
\hline
\end{tabular}

MP: Methylparaben, PP: Propylparaben, BP: Butylparaben.

bioaccumulate in fatty tissue. They can be accumulated in human breast tumors, with a mean concentration of $20.6 \pm 4.2 \mathrm{ng} / \mathrm{g}$ tissue [40]. Besides, a study on more than 1800 US people reported inverse associations between parabens concentration and circulating thyroid hormone levels in adults, mainly in females [47].

\subsubsection{Biologic monitoring}

There are several issues about the effect of long-term parabens exposure to the human body, leading to much research that detect paraben level in human samples. The human samples that can be used to detect parabens are tumor tissue, blood, human milk, seminal plasma, breast

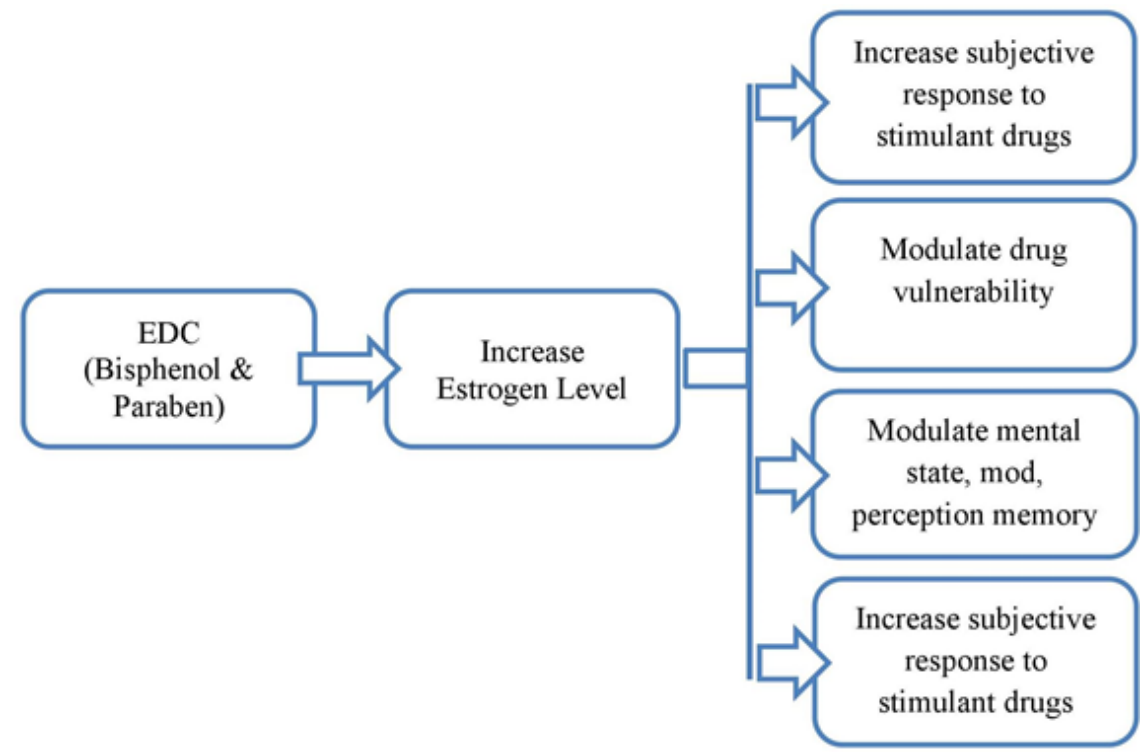

Figure 3. The Role of EDC

International Journal of Medical Toxicology \& forensic Medicine 
tissue, placental tissue, saliva, and urine (Table 4). Extraction and purification strategies (to disrupt the proteincompound binding and facilitate) are LLE, dispersive LLE, stir-bar sorptive extraction, supercritical extraction, solvent extraction, protein precipitation, SPE, and SPME. The analytical methods most commonly used for the determination of biomarkers or paraben exposure are LCMS/MS and GC-MS [48]. Samples in the pediatric patient are collected because pediatric liquid formulations contain excipients such as methylparaben and propylparaben [49].

\section{The Role of EDCs in drug abuse}

There is a strong association between hormonal factors and drug metabolism. EDCs can enhance estrogen levels in the body, and estrogen can increase the monoamine effect (dopamine, serotonin), neuronal excitability, neuropeptide transmitter mechanism, and drug metabolism. This mechanism can modulate mental state, mood, perception, behavior, memory, and drug vulnerability [50]. Some drug metabolism is faster in women than in men, so with the same dosage, it may exert different effects on men and women. The increase in dopamine can develop greater craving behavior, addiction, and relapse in drug abusers. Women have greater craving behavior in response to nicotine and cocaine, then more likely to relapse during and after the treatment, and have shorter abstinence periods after cocaine treatment, compared to men. Besides, estrogen may increase subjective response to stimulant drugs and accordingly increase craving behavior (Figure 3) [51].

\section{Conclusion}

Broadening our knowledge of the effects of bisphenol and parabens can increase the estrogen level. Increasing estrogen levels can influence the behavior, treatment, and prognosis of a drug addict. EDCs level in drug abusers is a challenging study to know the exposure of EDCs in the selected population, especially in a drug abuser.

\section{Ethical Considerations}

\section{Compliance with ethical guidelines}

Institutional approval for the analysis of human samples was obtained from the Ethical Committee of University Malaya Medical Centre

\section{Funding}

This research received research grant from Indonesia Endowment Fund for Education (LPDP, https://www.lpdp. kemenkeu.go.id/)

\section{Author's contributions}

Visualization, Writing - review \& editing: All authors; Supervision: Mustafa Ali Mohd, Rusdi bin Abd Rashid, Didi Erwandi bin Mohamad Haron; Investigation, Methodology, Resources, ROLES Conceptualization: Idha Arfianti Wiraagni, Mustafa Ali Mohd, Didi Erwandi bin Mohamad Haron; Data curation, Formal analysis, Software, Validation: Idha Arfianti Wiraagni, Didi Erwandi bin Mohamad Haron; ROLES Methodology: Rusdi bin Abd Rashid; Funding acquisition, Project administration: Idha Arfianti Wiraagni.

\section{Conflict of interest}

The authors declared no conflict of interests.

\section{Acknowledgements}

We thank Shimadzu-UM Center for Xenobiotics Studies (SUCXeS), LPDP Indonesia, and the Pathology Department UM for laboratory service establishment in this study.

\section{References}

[1] Hormann AM, vom Saal FS, Nagel SC, Stahlhut RW, Moyer $\mathrm{CL}$, Ellersieck MR, et al. Holding thermal receipt paper and eating food after using hand sanitizer results in high serum bioactive and urine total levels of bisphenol A (BPA). PLoS One. 2014; 9(10):e110509. [DOI:10.1371/journal.pone.0110509] [PMID] [PMCID]

[2] Lorber M, Schecter A, Paepke O, Shropshire W, Christensen K, Birnbaum L. Exposure assessment of adult intake of bisphenol A (BPA) with emphasis on canned food dietary exposures. Environ Int. 2015; 77:55-62. [DOI:10.1016/j.envint.2015.01.008] [PMID] [PMCID]

[3] Rouhani MH, Mirseifinezhad M, Omrani N, Esmaillzadeh A, Azadbakht L. Fast food consumption, quality of diet, and obesity among Isfahanian adolescent girls. J Obes. 2012; 2012:597924. [DOI:10.1155/2012/597924] [PMID] [PMCID]

[4] Gore AC, Crews D, Doan LL, La Merrill M, Patisaul H, Zota A. Introduction to endocrine disrupting chemicals (EDCs): A guide for public interest organizations and policy-makers [Internet]. 2014 [Updated 2014 December]. Available from: https://www.endocrine.org/-/media/endosociety/files/ advocacy-and-outreach/important-documents/introduction-to-endocrine-disrupting-chemicals.pdf

[5] Li DK, Zhou Z, Miao M, He Y, Wang JT, Ferber J, et al. Urine bisphenol-A (BPA) level in relation to semen qual- 
ity. Fertil Steril. 2011; 95(2):625-30.E4. [DOI:10.1016/j.fertnstert.2010.09.026] [PMID]

[6] Völkel W, Bittner N, Dekant W. Quantitation of bisphenol A and bisphenol A glucuronide in biological samples by high performance liquid chromatography-tandem mass spectrometry. Drug Metab Dispos. 2005; 33(11):1748-57. [DOI:10.1124/ dmd.105.005454] [PMID]

[7] Zhang Z, Alomirah H, Cho HS, Li YF, Liao C, Minh TB, et al Urinary bisphenol A concentrations and their implications for human exposure in several Asian countries. Environ Sci Technol. 2011; 45(16):7044-50. [DOI:10.1021/es200976k] [PMID]

[8] Zhang J, Li X, Zhou L, Wang L, Zhou Q, Huang X. Analysis of effects of a new environmental pollutant, bisphenol A, on antioxidant systems in soybean roots at different growth stages. Sci Rep. 2016; 6:23782. [DOI:10.1038/srep23782] [PMID] [PMCID]

[9] Zhang Z, Lin L, Gai Y, Hong Y, Li L, Weng L. Subchronic bisphenol $\mathrm{S}$ exposure affects liver function in mice involving oxidative damage. Regul Toxicol Pharmacol. 2018; 92:138-44. [DOI:10.1016/j.yrtph.2017.11.018] [PMID]

[10] Zhang Y, Qu B, Lun Sh, Wang D, Guo Y, Liu J. Quality of life of medical students in China: A study using the WHOQOL-BREF. PLoS One. 2012; 7(11):e49714. [DOI:10.1371/journal.pone.0049714] [PMID] [PMCID]

[11] Lehmler HJ, Liu B, Gadogbe M, Bao W. Exposure to bisphenol A, bisphenol F, and bisphenol S in U.S. adults and Children: The national health and nutrition examination survey 2013-2014. ACS Omega. 2018; 3(6):6523-32. [DOI:10.1021/ acsomega.8b00824] [PMID] [PMCID]

[12] Andra SS, Charisiadis P, Arora M, van Vliet-Ostaptchouk JV, Makris KC. Biomonitoring of human exposures to chlorinated derivatives and structural analogs of bisphenol A. Environ Int. 2015; 85:352-79. [DOI:10.1016/j.envint.2015.09.011] [PMID] [PMCID]

[13] Andra SS, Austin C, Yang J, Patel D, Arora M. Recent advances in simultaneous analysis of bisphenol $\mathrm{A}$ and its conjugates in human matrices: Exposure biomarker perspectives. Sci Total Environ. 2016; 572:770-81. [DOI:10.1016/j.scitotenv.2016.07.062] [PMID] [PMCID]

[14] Andrianou XD, Gängler S, Piciu A, Charisiadis P, Zira C, Aristidou K, et al. Human exposures to bisphenol A, bisphenol $\mathrm{F}$ and chlorinated bisphenol A derivatives and thyroid function. PLoS One. 2016; 11(10):e0155237. [DOI:10.1371/ journal.pone.0155237] [PMID] [PMCID]

[15] Lide DR, Baysinger G, Chemistry S, Berger LI, Goldberg RN, Kehiaian HV. CRC Handbook of Chemistry and Physics. :2661.

[16] Eladak S, Grisin T, Moison D, Guerquin MJ, N'Tumba-Byn T, Pozzi-Gaudin S, et al. A new chapter in the bisphenol A story: Bisphenol $S$ and bisphenol $F$ are not safe alternatives to this compound. Fertil Steril. 2015; 103(1):11-21. [DOI:10.1016/j. fertnstert.2014.11.005] [PMID]

[17] Galloway T, Cipelli R, Guralnik J, Ferrucci L, Bandinelli S, Corsi AM, et al. Daily bisphenol A excretion and associations with sex hormone concentrations: Results from the InCHIANTI adult population study. Environ Health Perspect. 2010; 118(11):1603-8. [DOI:10.1289/ehp.1002367] [PMID] [PMCID]
[18] Geueke B. FPF dossier: Bisphenol S [Internet]. 2015 [Updated 2015 November 9]. Available from: https://zenodo. org/record/33516

[19] Caballero-Casero N, Lunar L, Rubio S. Analytical methods for the determination of mixtures of bisphenols and derivatives in human and environmental exposure sources and biological fluids. A review. Anal Chim Acta. 2016; 908:22-53. [DOI:10.1016/j.aca.2015.12.034] [PMID]

[20] Nam SH, Seo YM, Kim MG. Bisphenol A migration from polycarbonate baby bottle with repeated use. Chemosphere. 2010; 79(9):949-52. [DOI:10.1016/j.chemosphere.2010.02.049] [PMID]

[21] Volkel W. Quantitation of Bisphenol A and Bisphenol A Glucuronide in Biological Samples by High Performance Liquid Chromatography-Tandem Mass Spectrometry. Drug Metabolism and Disposition. 2005; 33(11):1748-57. [DOI:10.1124/ dmd.105.005454] [PMID]

[22] Genuis SJ, Beesoon S, Birkholz D, Lobo RA. Human excretion of bisphenol A: Blood, Urine, and Sweat (BUS) study. J Environ Public Health. 2012; 2012:185731. [DOI:10.1155/2012/185731] [PMID] [PMCID]

[23] Buck Louis GM, Peterson CM, Chen Z, Croughan M, Sundaram R, Stanford J, et al. Bisphenol A and phthalates and endometriosis: The endometriosis: Natural history, diagnosis and outcomes study. Fertil Steril. 2013; 100(1):162-9.e1-2. [DOI:10.1016/j.fertnstert.2013.03.026] [PMID] [PMCID]

[24] Ihde ES, Zamudio S, Loh JM, Zhu Y, Woytanowski J, Rosen $\mathrm{L}$, et al. Application of a novel Mass Spectrometric (MS) method to examine exposure to bisphenol-A and common substitutes in a maternal fetal cohort. Hum Ecol Risk Assess. 2018; 24(2):331-46. [DOI:10.1080/10807039.2017.1381831] [PMID] [PMCID]

[25] Meeker JD, Yang T, Ye X, Calafat AM, Hauser R. Urinary concentrations of parabens and serum hormone levels, semen quality parameters, and sperm DNA damage. Environ Health Perspect. 2011; 119(2):252-7. [DOI:10.1289/ehp.1002238] [PMID] [PMCID]

[26] Mok-Lin E, Ehrlich S, Williams PL, Petrozza J, Wright DL, Calafat AM, et al. Urinary bisphenol A concentrations and ovarian response among women undergoing IVF. Int J Androl. 2010; 33(2):385-93. [DOI:10.1111/j.13652605.2009.01014.x] [PMID] [PMCID]

[27] Mokra K, Woźniak K, Bukowska B, Sicińska P, Michałowicz J. Low-concentration exposure to BPA, BPF and BPAF induces oxidative DNA bases lesions in human peripheral blood mononuclear cells. Chemosphere. 2018; 201:119-26. [DOI:10.1016/j.chemosphere.2018.02.166] [PMID]

[28] Michałowicz J, Mokra K, Bąk A. Bisphenol A and its analogs induce morphological and biochemical alterations in human peripheral blood mononuclear cells (in vitro study). Toxicol In Vitro. 2015; 29(7):1464-72. [DOI:10.1016/j.tiv.2015.05.012] [PMID]

[29] Wolff MS, Britton JA, Boguski L, Hochman S, Maloney N, Serra N, et al. Environmental exposures and puberty in innercity girls. Environ Res. 2008; 107(3):393-400. [DOI:10.1016/j. envres.2008.03.006] [PMID] [PMCID]

[30] Wolff MS, Engel SM, Berkowitz GS, Ye X, Silva MJ, Zhu $\mathrm{C}$, et al. Prenatal phenol and phthalate exposures and birth 
outcomes. Environ Health Perspect. 2008; 116(8):1092-7. [DOI:10.1289/ehp.11007] [PMID] [PMCID]

[31] Braun JM, Yolton K, Dietrich KN, Hornung R, Ye X, Calafat AM, et al. Prenatal bisphenol A exposure and early childhood behavior. Environ Health Perspect. 2009; 117(12):1945-52. [DOI:10.1289/ehp.0900979] [PMID] [PMCID]

[32] Matuszczak E, Komarowska MD, Debek W, Hermanowicz A. The impact of bisphenol A on fertility, reproductive system, and development: A review of the literature. Int J Endocrinol. 2019; 2019:4068717. [DOI:10.1155/2019/4068717] [PMID] [PMCID]

[33] Moon MK. Concern about the safety of bisphenol A substitutes. Diabetes Metab J. 2019; 43(1):46-8. [DOI:10.4093/ dmj.2019.0027] [PMID] [PMCID]

[34] Vandenberg LN, Hauser R, Marcus M, Olea N, Welshons WV. Human exposure to bisphenol A (BPA). Reprod Toxicol. 2007; 24(2):139-77. [DOI:10.1016/j.reprotox.2007.07.010] [PMID]

[35] Vandenberg LN, Gerona RR, Kannan K, Taylor JA, van Breemen RB, Dickenson CA, et al. A round robin approach to the analysis of Bisphenol A (BPA) in human blood samples. Environ Health. 2014; 13(1):25. [DOI:10.1186/1476069X-13-25] [PMID] [PMCID]

[36] Asimakopoulos AG, Thomaidis NS, Koupparis MA. Recent trends in biomonitoring of bisphenol A, 4-t-octylphenol, and 4-nonylphenol. Toxicol Lett. 2012; 210(2):141-54. [DOI:10.1016/j.toxlet.2011.07.032] [PMID]

[37] Markham DA, Waechter Jr JM, Wimber M, Rao N, Connolly P, Chuang JC, et al. Development of a method for the determination of bisphenol $\mathrm{A}$ at trace concentrations in human blood and urine and elucidation of factors influencing method accuracy and sensitivity. J Anal Toxicol. 2010; 34(6):293-303. [DOI:10.1093/jat/34.6.293] [PMID]

[38] Liao C, Liu F, Alomirah H, Loi VD, Mohd MA, Moon HB, et al. Bisphenol $S$ in urine from the United States and seven Asian countries: Occurrence and human exposures. Environ Sci Technol. 2012; 46(12):6860-6. [DOI:10.1021/es301334j] [PMID]

[39] Genuis SJ, Birkholz D, Curtis L, Sandau C. Paraben levels in an urban community of Western Canada. ISRN Toxicol. 2013; 2013:507897. [DOI:10.1155/2013/507897] [PMID] [PMCID]

[40] Darbre PD, Aljarrah A, Miller WR, Coldham NG, Sauer MJ, Pope GS. Concentrations of parabens in human breast tumours. J Appl Toxicol. 2004; 24(1):5-13. [DOI:10.1002/jat.958] [PMID]

[41] Yamamoto H, Tamura I, Hirata Y, Kato J, Kagota K, Katsuki $\mathrm{S}$, et al. Aquatic toxicity and ecological risk assessment of seven parabens: Individual and additive approach. Sci Total Environ. 2011; 410-411:102-11. [DOI:10.1016/j.scitotenv.2011.09.040] [PMID]

[42] Engeli R, Rohrer S, Vuorinen A, Herdlinger S, Kaserer T, Leugger $S$, et al. Interference of paraben compounds with estrogen metabolism by inhibition of $17 \beta-H y d r o x y s t e r o i d ~ d e-$ hydrogenases. Int J Mol Sci. 2017; 18(9):2007. [DOI:10.3390/ ijms18092007] [PMID] [PMCID]

[43] Ye X, Bishop AM, Reidy JA, Needham LL, Calafat AM. Parabens as urinary biomarkers of exposure in humans. Environ Health Perspect. 2006; 114(12):1843-6. [DOI:10.1289/ ehp.9413] [PMID] [PMCID]
[44] Dewalque L, Pirard C, Dubois N, Charlier C. Simultaneous determination of some phthalate metabolites, parabens and benzophenone- 3 in urine by ultra high pressure liquid chromatography tandem mass spectrometry. J Chromatogr B Analyt Technol Biomed Life Sci. 2014; 949-950:37-47. [DOI:10.1016/j.jchromb.2014.01.002] [PMID]

[45] Larsson K, Ljung Björklund K, Palm B, Wennberg M, Kaj $\mathrm{L}$, Lindh $\mathrm{CH}$, et al. Exposure determinants of phthalates, parabens, bisphenol A and triclosan in Swedish mothers and their children. Environ Int. 2014; 73:323-33. [DOI:10.1016/j. envint.2014.08.014] [PMID] [PMCID]

[46] Abbas S, Greige-Gerges H, Karam N, Piet M-H, Netter P, Magdalou J. Metabolism of parabens (4-hydroxybenzoic acid esters) by hepatic esterases and UDP-glucuronosyltransferases in man. Drug Metab Pharmacokinet. 2010; 25(6):568-77. [DOI:10.2133/dmpk.DMPK-10-RG-013] [PMID]

[47] Koeppe ES, Ferguson KK, Colacino JA, Meeker JD. Relationship between urinary triclosan and paraben concentrations and serum thyroid measures in NHANES 2007-2008. Sci Total Environ. 2013; 445-446:299-305. [DOI:10.1016/j.scitotenv.2012.12.052] [PMID] [PMCID]

[48] Yusa V, Ye X, Calafat AM. Methods for the determination of biomarkers of exposure to emerging pollutants in human specimens. Trends Analyt Chem. 2012; 38:129-42. [DOI:10.1016/j.trac.2012.05.004] [PMID] [PMCID]

[49] Yakkundi S, Mulla H, Pandya H, Turner MA, McElnay J. Quantitative analysis of methyl and propyl parabens in neonatal DBS using LC-MS/MS. Bioanalysis. 2016; 8(11):1173-82. [DOI:10.4155/bio-2016-0029] [PMID]

[50] Forray A, Sofuoglu M. Future pharmacological treatments for substance use disorders. Br J Clin Pharmacol. 2014 77(2):382-400. [DOI:10.1111/j.1365-2125.2012.04474.x] [PMID] [PMCID]

[51] Wilcox C, Brizendine L. For women only: Hormones may prevent addiction relapse. Current Psyciatry. 2006; 5(8)4052. https://www.mdedge.com/psychiatry/article/62295/ women-only-hormones-may-prevent-addiction-relapse 